\title{
Evaluation of the Solid and Hazardous Wastes Generated by the Automotive Industry in Turkey
}

\author{
B. Erdogan, G. Salihoglu* \\ Department of Environmental Engineering, University of Uludag, Bursa, 16059, Turkey
}

\begin{abstract}
Development of the automotive industry not only facilitated our daily lives, but also introduced environmental stress. The automotive industry consists of both the original equipment manufacturers (OEMs), and a great variety of suppliers that support this industry. Most of the published studies focus on the environmental impacts of the OEMs; the impacts of suppliers were generally neglected. The objective of this study was to evaluate the types and amounts of solid and hazardous wastes generated by the automotive industry especially in relation to the supplier companies supporting the automotive manufacturers in Turkey. A survey was conducted with representative numbers of automotive manufacturers and suppliers located in Bursa, Turkey to obtain data on resource usage, waste types, and waste amounts generated. One hundred and five different parts of an automobile were examined in the framework of the study. Interviews were also conducted with the suppliers about the details on each item produced. Resource usage, solid and hazardous waste generation during the production of each component of an automobile were calculated. The environmental burden of the automotive industry in Turkey was roughly calculated in terms of waste generation and resource usage based on energy and water. It was seen that of the items constituting an automobile, which are provided by the suppliers, $47 \%$ is made of plastics, $31 \%$ is made of textile, and $21 \%$ is made of metals. The amounts of water and electricity used for all the items by the suppliers were found as $0.60 \mathrm{~m}^{3} /$ vehicle and $190 \mathrm{kWh} /$ vehicle, respectively. Water and electricity usage by OEMs were $3.47 \mathrm{~m}^{3} /$ vehicle and $1763 \mathrm{kWh} /$ vehicle, respectively. Solid and hazardous waste generated by OEMs were found as $48.97 \mathrm{~kg} /$ vehicle and $7.04 \mathrm{~kg} /$ vehicle, respectively, and by suppliers were $5.71 \mathrm{~kg} /$ vehicle and $0.6 \mathrm{~kg} /$ vehicle, respectively.
\end{abstract}

Keywords: OEM, supplier companies, questionnaire, automobile components

\section{Introduction}

The fact that automobiles are indispensable in our modern daily lives leaded the automotive industry to become a large and influential industry. Steel, plastic, rubber, and other industries for raw materials were stimulated by the development of the automotive industry [1]. As a result, the management practices of automotive industry started to have an influence on many other business sectors [2].

Development of the automotive industry not only facilitated our daily lives, but also introduced environmental pressures [2]. Liu,

${ }^{*}$ Corresponding author: Guray Salihoglu

Tel.: +90-224-2942120, E-mail: gurays@uludag.edu.tr

(c) 2018 International Association for Sharing Knowledge and Sustainability

DOI: $10.5383 /$ ijtee.16.02.003
Liu and Chen [1] conducted a life cycle assessment (LCA) to assess the environmental impacts at the manufacturing and consumption stages of Chinese automotive industry, and reported that the automotive industry significantly impacts the environment in China. The researchers also stated that the indirect impacts at the manufacturing stage and direct impacts at the consumption stage dominate the total environmental impacts [1].

The automotive industry is known as the most resource intensive industry of all major industries [3]. Especially the acquisition and processing of virgin resources to be used as raw material in the manufacturing stage is reported to include substantial consumption of material and energy [3]. Energy consumption is substantial in heating, cooling, and production of raw materials 
such as steel, aluminum, plastic, and glass [3]. Similarly the manufacturing process results in the consumption of several natural sources such as water, natural gases, raw materials, and the generation of various hazardous and non-hazardous types of wastes. The global vehicle production has been increasing at a constant rate and this increase is expected to continue, implying that the environmental burden of the automotive manufacturing process will continue to increase.

Sustainability research related to automotive industry can be categorized into four main areas: the life cycle assessment approach, the end-of-life perspective, the design for sustainability, and light-weight engineering \& material selection [4]. Environmental impacts of the automotive industry were generally evaluated for the whole industry in a systemic way, for the supply chain, and for a single automobile component. Vinodh and Jayakrishna [5] investigated the potential of environmental impact minimization using alternative materials and alternative manufacturing process. Jabbour, et al. [6] analyzed the influence of environmental management on operational performance of Brazilian automotive companies. Factors influencing the energy intensity of automotive plants were investigated by using a multiple linear regression approach by Dehning, et al. [7]. Sullivan, et al. [8] presented a model for calculating the environmental burdens of the part manufacturing and vehicle assembly stages. Hakamada, et al. [9] reported on the effect of Mg substitution for steel parts in a vehicle on energy consumption and emissions. Geyer [10] made a parametric assessment of climate change impacts of automotive material substitution, while Sim and Sim [11] assessed air emissions from finished vehicles. Research on automotive industry is also dedicated to investigate green or sustainable supply chain management practices and to develop models [12-15]. Life cycle assessments for automobile components such as exterior door skin [16], multi-material component for brake system [17], composite material for vehicle dashboard [18] were also undertaken. Limited studies exist on the solid wastes from automotive industry and their management. Tian, et al. [19] investigated the automotive components remanufacturing industry, and Handoko, et al. [20] studied production of ceramic materials from automotive shredder residue waste. Liu, et al. [21] investigated the recycling potential of automotive shredder residue waste as a lightweight aggregate. Salihoglu and Salihoglu [22] focused on the management of the paint sludge generated by automotive industries. Although many papers were published on life cycle analysis germane to automotive industry, which require an extensive amount of data inventory, very limited amount of data were submitted on the actual amounts of the waste generated, except for the sustainability reports of known automotive companies.

The automotive industry consists of not only the original equipment manufacturers (OEMs), but also a great variety of suppliers that support OEMs as well. The number and capacity of the facilities serving this industry have been improving according to the demand for the automobiles; the number, capacity, and the diversity of the supplier companies have been increasing in parallel. Although studies have been published on the environmental impacts of automotive industry as a whole and of several components of a vehicle, the environmental impact of the automotive supplier companies has not been researched in depth. Additionally, nationwide environmental impacts of Turkish automotive industry including the supplier companies have not been evaluated as a whole. Although known automotive companies publish sustainability reports [23-28] to promulgate their environmental impact, they do not mention the supplier companies that support them. The objective of this study is to contribute to the evaluation of the environmental burden of Turkish automotive industry by evaluating the resource usage and waste generation by the automotive industry by relating certain supplier companies supporting the automotive manufacturers in Turkey.

The development of the automotive industry in Turkey dates back to 1960s [29]. Currently, there are 14 automotive manufacturing companies in Turkey, where 1,235,000 automobiles were manufactured in 2016 [29]. Automotive companies are mostly located in cities of Bursa, Istanbul, Kocaeli, and Ankara. In the city of Bursa, there are 3 automotive manufacturers (OEMs) and a considerable number of suppliers (three hundred thirty four) for every components of an automobile. As the vehicle production capacity is considered, the potential environmental load of the supplier companies would be obvious, which needs to be assessed, which this work will address. To this aim, data on the resource usage (water and electricity) and waste generation (types and amounts of solid and hazardous waste) by the supplier companies were collected via questionnaires, and evaluated combining with the data from sustainability reports.

\section{Materials \& Methods}

A survey was conducted with representative numbers of automotive manufacturers and suppliers located in Bursa to obtain data on the waste types and amounts generated. A questionnaire was prepared and applied to 25 companies in Bursa. Data on the raw materials used, consumption of natural resources, wastes generated (EWC codes, types, amounts) and waste disposal routes were collected via the questionnaire. The questionnaire used is given in Annex 1. Over 100 different parts of an automobile were examined in the framework of the study. Only the automobile engine, which is not produced in Turkey, and very small items such as pin bolts, screws, and ring nuts were excluded from this study. Of the items constituting an automobile, $47 \%$ is made of plastics, $31 \%$ is made of textile, and $21 \%$ is made of metals. Interviews were also conducted with automotive suppliers about the details of each item produced. Fig.1 shows the automobile components, of which manufacturing waste data was collected in this study. 


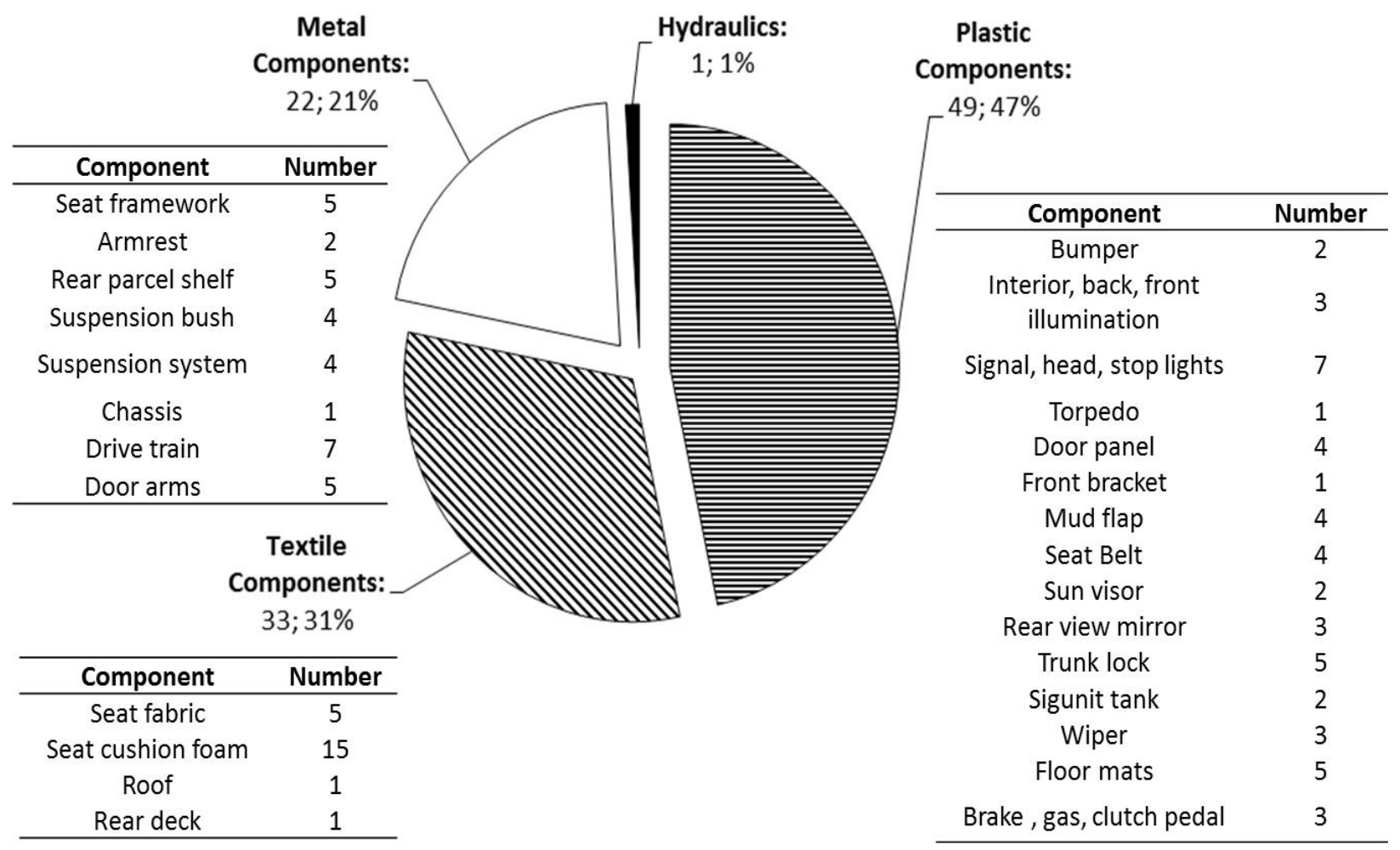

Fig. 1. Automobile components investigated

\section{Results \& Discussion}

\subsection{Raw Material Usage by Supplier Companies}

Supplier companies serve to a variety of needs for an automobile. Plastic parts are required for components such as door panel, hood, illuminations, wiper, sun visor, whilst textile products are necessary for seat, roof, seat fabric and foam, real parcel shelf. Furthermore metal products are used for seat structure, roof, chassis and drive train. More specifically, metal raw materials can be listed as cold-rolled iron, hot-rolled iron, and various sizes of screws, iron pipes, aluminum pipes and plates, composite materials, tin plates, steel plates. Plastics and chemicals used can be grouped as PVC plates, polyethylene, polypropylene, ABS, polyamide, rubber, Woodstock plate, isocyanate, and polyol. Textile components used consist of glass fiber, glue, foam, felting, and fabric. Table 1 lists raw materials used by supplier companies and the waste generated per product; the data was collected via the questionnaire. It can be seen from the table that sometimes many different types of raw materials can be used for very small items. Highest amount of raw material, which is about $7 \mathrm{~kg}$, is spent for the production of seat structure, followed by drive train.

\subsection{Raw Material Usage by OEMs}

OEMs assemble the semi-finished products produced by the supplier companies. The activities by the OEMs can be grouped as stamping, welding, painting, and assembly [30]. Therefore the raw materials at this point are mostly the semi-finished products from the supplier companies. Besides, a variety of chemicals, fuel tanks, oil drums and compressed gas cylinders, and solvents are used for the process steps of stamping, welding, painting, and assembly by the OEMs. According to the interviews made with an automotive manufacturer in Bursa, which produce 400,000 vehicles/year, the number of the chemicals used mounts to approximately 800 . During the stamping step, 20 types of chemicals, which amount to 3.3 tons/year, are used. During the welding step, 43 different chemicals of 13 tons/year; during the painting step, 86 chemicals of 360 tons/year; and during the assembly step, 36 chemicals of 63 tons/year are used by the OEMs. 481 supplementary chemicals of 416 tons/year are used as well. Besides, 26 chemicals of 2.2 tons/year are consumed for research and development activities. 
Table 1 Raw materials used by supplier companies and the waste generated per product

\begin{tabular}{|c|c|c|c|}
\hline $\begin{array}{l}\text { Name of the } \\
\text { product }\end{array}$ & $\begin{array}{c}\text { Amount of } \\
\text { Raw Material } \\
\text { Used (kg) }\end{array}$ & Raw Materials Used & $\begin{array}{c}\text { Waste } \\
\text { Generated (kg) } \\
\text { (hazardous \& } \\
\text { non-hazardous) }\end{array}$ \\
\hline Bumpers & 2.00 & Polypropylene, Polyamide, ABS, Polyethylene & 0.714 \\
\hline Lightings & 0.99 & Rear View Mirror, Polypropylene, Polyamide, ABS, Polyethylene & 0.183 \\
\hline Door Panels & 3.96 & Polypropylene, Polyamide, ABS, Polyethylene & 0.284 \\
\hline Door Pocket & 0.79 & Polypropylene, Polyamide, ABS, Polyethylene & 0.051 \\
\hline Mud Flaps & 1.80 & Polypropylene, Polyamide, ABS, Polyethylene & 0.144 \\
\hline Seat Belts & 6.60 & PE-Foam, PVC Plate, Polypropylene, Polyamide, ABS, Polyethylene & 0.945 \\
\hline Sun Visor & 2.24 & PE-Foam, Polyethylene, Mirror & 0.268 \\
\hline Rear View Mirror & 0.27 & Rear View Mirror, PVC Plate & 0.061 \\
\hline Rear Parcel Shelf & 1.10 & Staple Sliver, Rigid Foam, Glue, Solvent Woodstock Plate, Felting & 0.396 \\
\hline Suspension Ring & 1.00 & $\begin{array}{l}\text { Cold-rolled Materials, Steel Tube, Round Steel, Flat Steel, Aluminum Pipe, } \\
\text { Aluminum Plate, Rubber, Plastic Parts }\end{array}$ & 0.039 \\
\hline Suspension Systems & 1.00 & $\begin{array}{l}\text { Cold - rolled Materials, Hot - rolled Materials, Iron Pipe, Line Shaft, Composite } \\
\text { Screw }\end{array}$ & 0.763 \\
\hline Covering & 0.02 & Acetic Acid, Phenol, Phosphoric Acid, pH adjust, Wetting Materials, Liquid Caustic & 0.008 \\
\hline Drive Train & 4.28 & Cold-rolled Materials, Hot-rolled Materials, Iron Pipe, Line Shaft, Composite Screw & 0.763 \\
\hline Hood & 1.42 & Cold-rolled Materials, Hot-rolled Materials, Iron Pipe, Line Shaft, Composite Screw & 0.763 \\
\hline $\begin{array}{l}\text { Pedals, Door Lock, } \\
\text { Water Tank }\end{array}$ & 1.19 & Sheet Metal, Plastic, Polypropylene, ABS, Polyethylene & 0.107 \\
\hline Seat Structure & 7.00 & Cold-rolled Materials, Hot-rolled Materials, Iron Pipe, Line Shaft, Composite Screw & 0.004 \\
\hline $\begin{array}{l}\text { Seat Foam and Seat } \\
\text { Fabric }\end{array}$ & 2.00 & $\begin{array}{l}\text { Staple Sliver, Rigid Foam, Glue, Solvent, Woodstock Plate, Felting, Isocyanate, } \\
\text { Polyol, glass fiber, fabric }\end{array}$ & 0.025 \\
\hline
\end{tabular}

\subsection{Resource Usage by the Automotive Supplier Companies}

Resources usage in terms of water and electricity was investigated by evaluating the data collected via the questionnaire.
Fig. 2 shows the amount of water consumed for each item, being produced by the supplier companies. Seat belt, followed by sun visor and seat fabric \& foam are the products where water is consumed most. Production of suspension systems necessitated the least amount of water consumption among others. The amount of the water used for all the items by the supplier companies was found to be approximately $0.60 \mathrm{~m}^{3} / \mathrm{car}$.

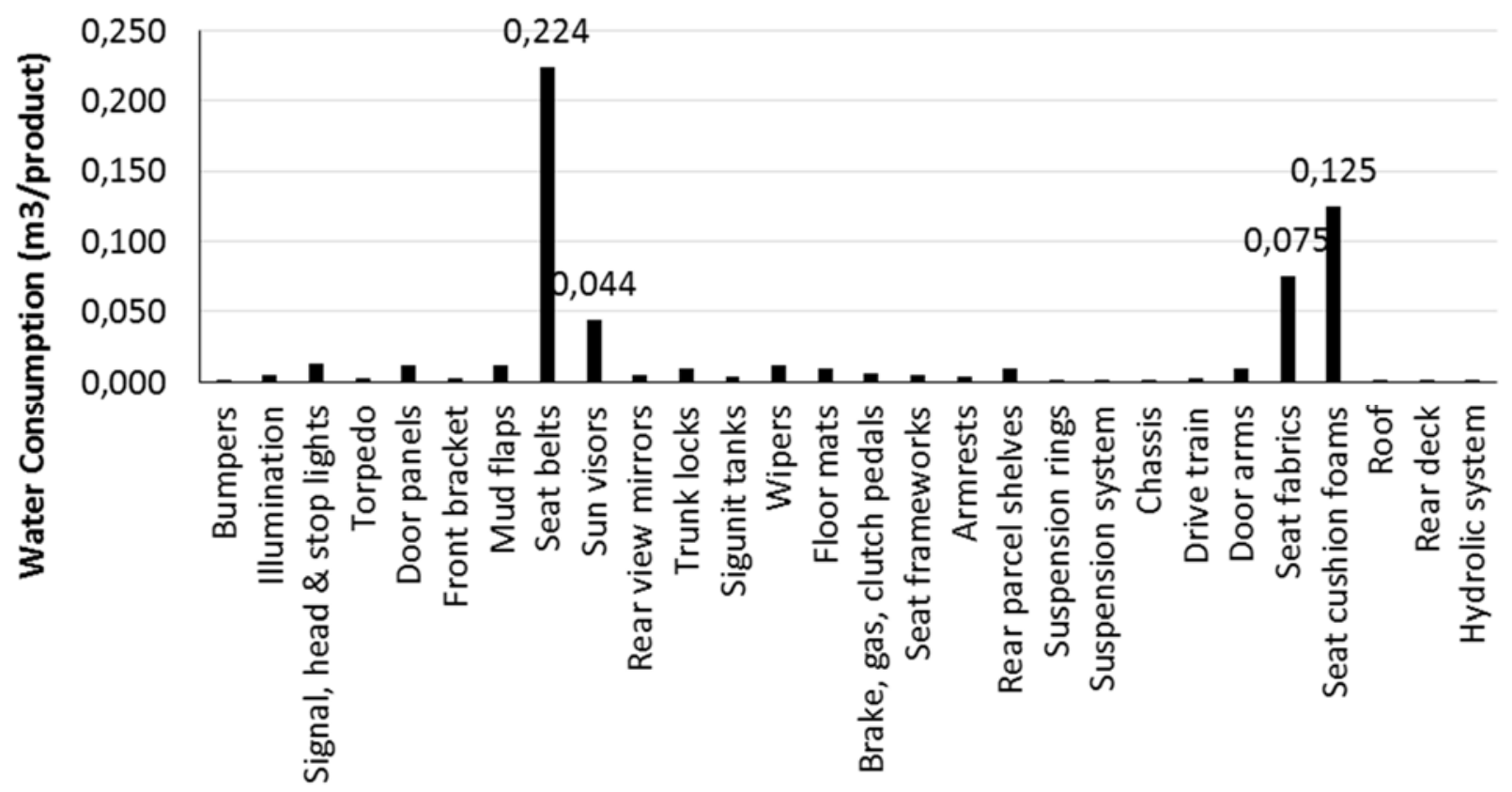

Fig. 2. Water consumption per product by the automotive supplier companies investigated (m3/product) 
Fig. 3 shows the electricity consumption per product by the supplier companies. In parallel to the water consumption levels, highest electricity consumption among all items were found for the production of seat belts, followed by sun visor, and seat fabric \& foam. The amount of the electricity used for all the items by the supplier companies was found to be approximately $190 \mathrm{kWh} / \mathrm{car}$.

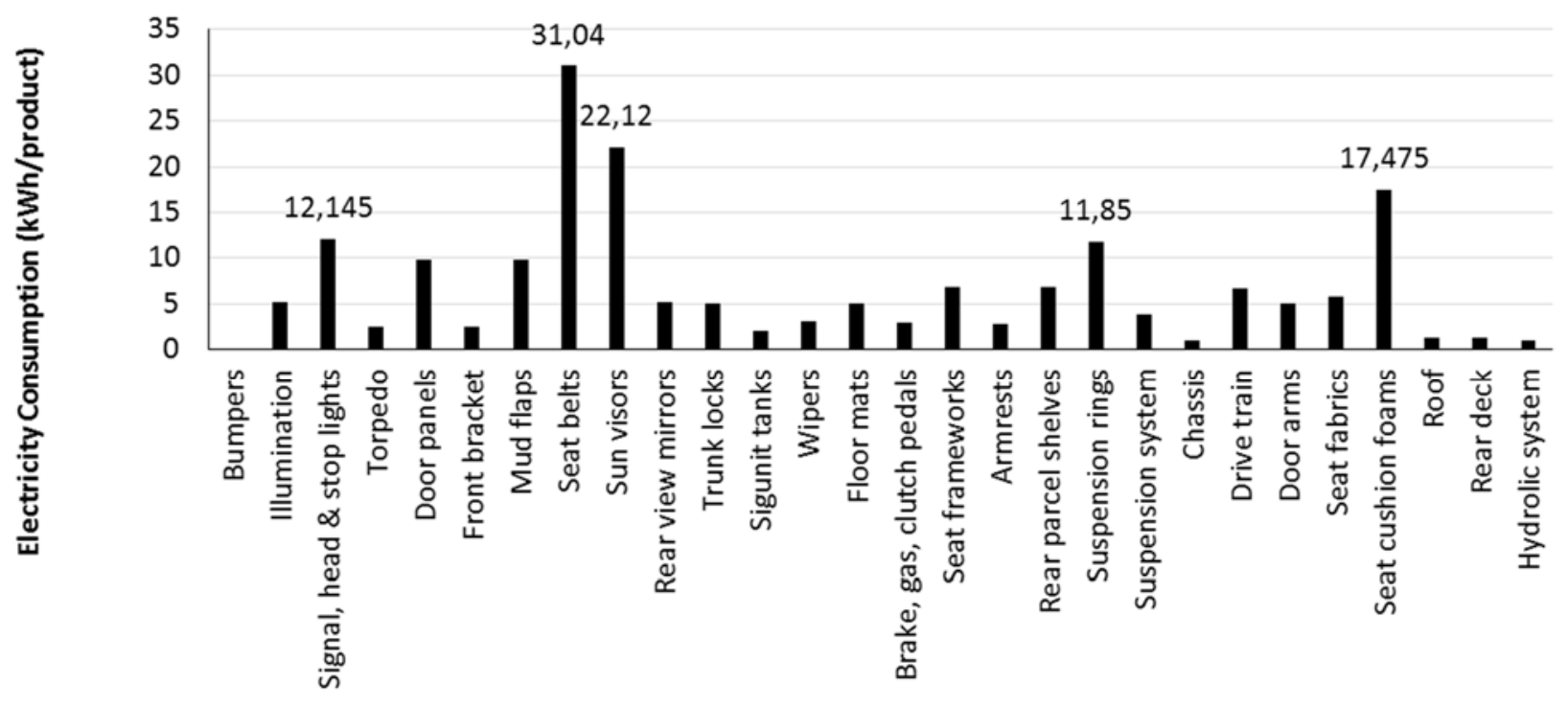

Fig. 3. Electricity consumption per product by the automotive supplier companies investigated (kWh/product)

\subsection{Resource Usage by OEMs}

Data from the sustainability reports [24-26, 28, 31-34] were compiled to evaluate the use of natural resources by the OEMs. Fig. 4 shows the water consumption levels by several automotive manufacturers globally. Water usage during the production ranges between 2.18-5.57 m3/vehicle. Fig. 5 shows the electricity consumption levels by several automotive manufacturers. Electricity usage during production of a vehicle ranges between 297-2659 $\mathrm{kWh}$, the average amount was calculated as $1763 \mathrm{kWh}$.

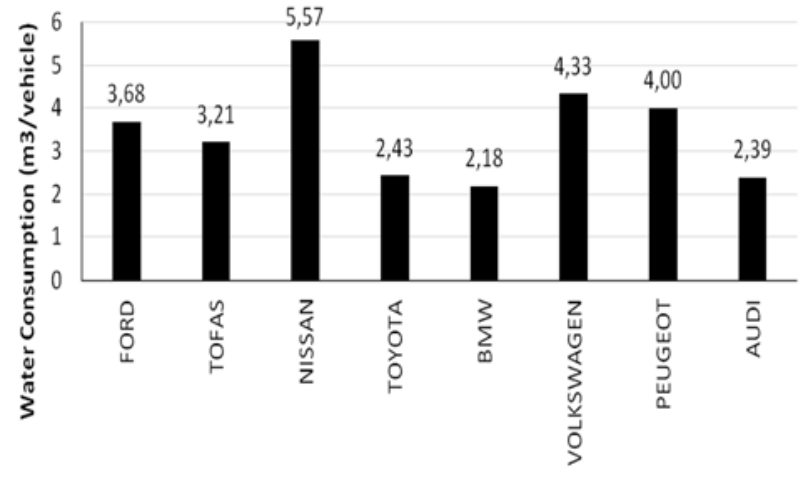

Fig. 4. Water consumption per vehicle by several automotive companies globally (m3 /vehicle)

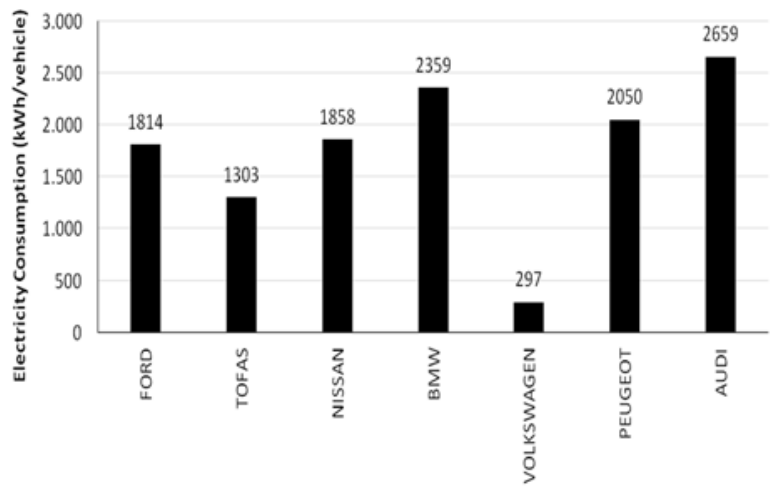

Fig. 5. Electricity Consumption per vehicle by several automotive companies globally (kWh/vehicle)

\subsection{Waste Generated by the Supplier Companies \& OEMs}

The sectors of automotive supplier companies can be grouped as metal, plastic, and textile industries. The distribution of the wastes according to these sectors is as follows: $45 \%$ of the total waste by suppliers is generated by plastics industry, whereas $28 \%$ and $26 \%$ are generated by metal and textile industries, respectively. $90.5 \%$ of the wastes generated by the supplier companies were found to be non-hazardous while $9.5 \%$ were hazardous. The amount of waste generated during the production of all items by supplier companies amounts to 6.31 $\mathrm{kg} / \mathrm{vehicle.}$ 
The amounts and types of the wastes generated by the supplier companies were determined by evaluating the data from the results of the questionnaire. Total amount of waste and hazardous waste generated for production of each item by the supplier companies are given in Fig. 6 and Fig. 7, respectively. Waste amounts and raw materials used for each item produced can be also found in Table 1 .

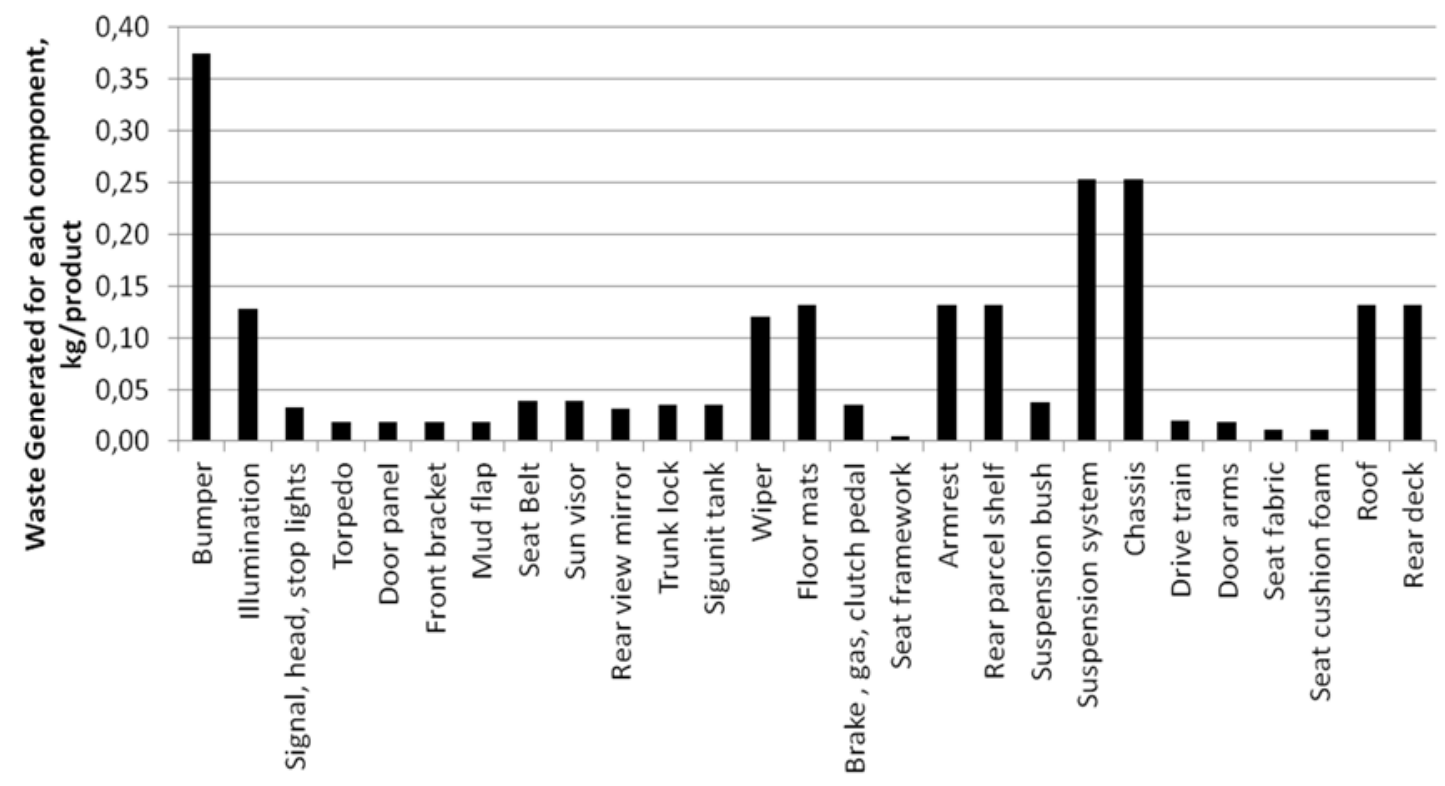

Fig. 6. Total amount of waste per product (kg/product)

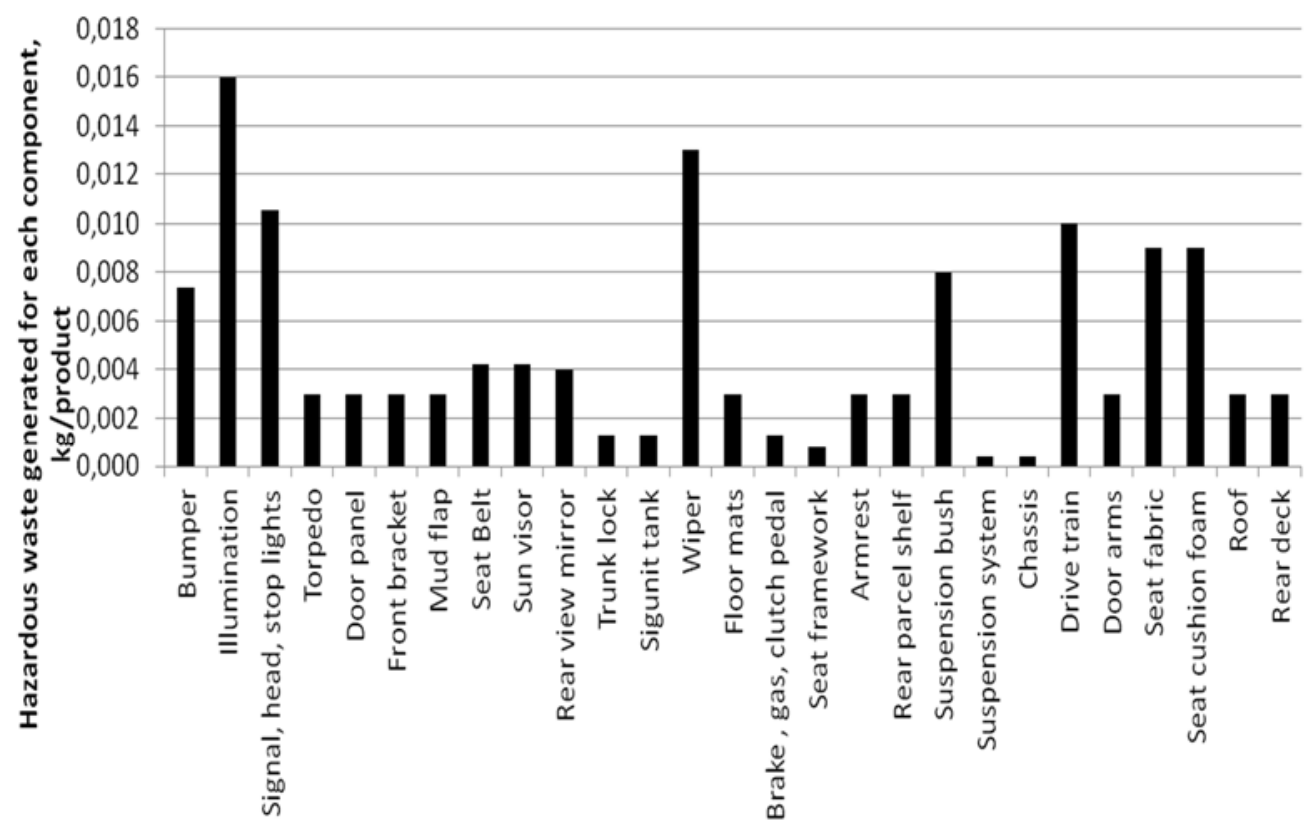

Fig. 7. Total amount of hazardous waste per product (kg/product)

According to Fig. 6 the amount of the solid waste generated from bumper production was found to have the highest production among all items produced by the suppliers, which is followed by the amount of the waste to produce suspension systems and chassis. Bumper is a big sized product compared to the other components; therefore high amount of waste for this item is reasonable.
Fig. 7 shows that highest amount of hazardous waste among all items, which is $0.016 \mathrm{~kg} /$ product, is generated during the production of illumination items, which is followed by wipers and wiper systems. The amount of the hazardous waste generated during the production of signal, head \& stop lights are the third after illumination and wipers. The variety of the raw material for these items is also more than that of the others. 
Total amount of waste generated during the stamping, welding, painting, and assembly processes by the OEMs amounts to 56 $\mathrm{kg} /$ vehicle, of which $12.5 \%$ is hazardous [30]. In total, 62.3 $\mathrm{kg} /$ vehicle solid waste is generated for the production of a standard vehicle by supplier companies and the OEMs. Approximately $10 \%$ of the total solid waste is generated by the supplier companies. It can be inferred that despite the large variety of the supplier companies and their sectors, OEMs are still the predominant source of waste from automotive sector. The amounts of waste generation rates during the production of vehicles can be found in the sustainability reports published. Accordingly average waste amounts generated per vehicle by the main automotive companies is given in Figure 8.

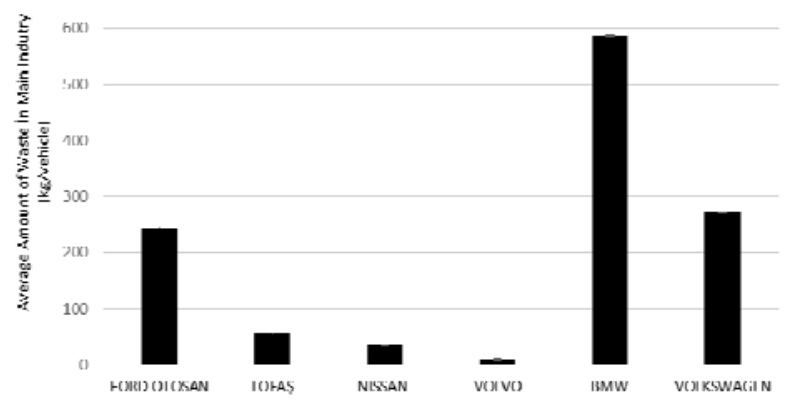

Fig. 8. Average amounts of solid wastes generated by OEMs (kg/vehicle)
Fig. 8 shows that highest amount is being generated by the companies that are manufacturing not only passenger cars, but also larger-size vehicles such as, buses, minibuses, engines as well.

Automotive supplier companies were examined on a sector basis, and the average percentages of packaging wastes generated by the plastics, metal, and textile sectors involved were found to be $43 \%, 31 \%$, and $26 \%$, respectively. The reason behind the finding of the highest amount of packaging waste being generated by plastics sector, may be attributed to the fact that plastic parts consist of visual parts of the vehicle, which are packaged more than the other parts to avoid damages. Table 2 gives the waste types generated by the automotive supplier companies and their disposal routes.

The resource usage and waste generation during the production of a vehicle is summarized per fig. 9 . It can be seen that although the resource usage and waste generation is much higher than that of the suppliers, the environmental burden of the suppliers is still at a considerable level. Automobile engine, which is not produced in Turkey, was excluded from the boundaries of this study. Approximately, 840,000 vehicles/year are produced in Turkey. According to the findings of this study, the total amount of solid waste generated during the production of these vehicles can be calculated as 52,340 tonnes of which 6,417 tonnes are hazardous. Water usage by the automotive sector amounts to 3.42 million m3/year, and electricity consumption is about 1,640,520 MWh.

Table 2. Waste types generated by suppliers and their disposal routes

\begin{tabular}{|c|c|c|c|}
\hline Code of the Waste & Name of the Waste & Sector & $\begin{array}{l}\text { Disposal } \\
\text { Method* }\end{array}$ \\
\hline \multirow[t]{3}{*}{130113} & \multirow[t]{3}{*}{ Other Hydrolic Oils } & Plastic Industry & R9 \\
\hline & & Metal Industry & R9 \\
\hline & & Textile Industry & R9 \\
\hline \multirow[t]{3}{*}{150101} & \multirow[t]{3}{*}{ Paper Carton Packging } & Plastic Industry & R11 \\
\hline & & Metal Industry & R11 \\
\hline & & Textile Industry & R11 \\
\hline \multirow[t]{3}{*}{150102} & \multirow[t]{3}{*}{ Plastic Packging } & Plastic Industry & R7 \\
\hline & & Metal Industry & R7 \\
\hline & & Textile Industry & R7 \\
\hline \multirow[t]{3}{*}{150110} & & Plastic Industry & $\mathrm{R} 12$ \\
\hline & \multirow{2}{*}{$\begin{array}{l}\text { Containers containing hazardous substances or contaminated with dangerous } \\
\text { substances }\end{array}$} & Metal Industry & $\mathrm{R} 12$ \\
\hline & & Textile Industry & R12 \\
\hline \multirow[t]{3}{*}{150111} & \multirow{3}{*}{$\begin{array}{l}\text { Metallic packages of dangerous porous solid structures (eg asbestos), including } \\
\text { empty pressure containers }\end{array}$} & Plastic Industry & R13 \\
\hline & & Metal Industry & R13 \\
\hline & & Textile Industry & R13 \\
\hline \multirow[t]{3}{*}{150202} & \multirow{3}{*}{$\begin{array}{l}\text { Dangerous materials contaminated absorbents, filter materials (oil filters if not } \\
\text { otherwise specified), cleaning cloths, protective clothing }\end{array}$} & Plastic Industry & R12 \\
\hline & & Metal Industry & R12/R13 \\
\hline & & Textile Industry & R12 \\
\hline \multirow[t]{3}{*}{180103} & \multirow{3}{*}{$\begin{array}{l}\text { To prevent infection, collect wastes and dispose of wastes subject to special } \\
\text { treatment }\end{array}$} & Plastic Industry & D9 \\
\hline & & Metal Industry & D9 \\
\hline & & Textile Industry & D9 \\
\hline \multirow[t]{3}{*}{200121} & \multirow{3}{*}{ Fluorescent lamps and other mercury-containing wastes } & Plastic Industry & R13 \\
\hline & & Metal Industry & R13 \\
\hline & & Textile Industry & R13 \\
\hline
\end{tabular}

*Explanations of disposal methods are as follows:

R7: Recycling of parts (components) used to reduce pollution,

R9: Refining or other re-use of waste oils

R11: Use of wastes from operations R1 to R10

R12:The exchange of wastes to be subjected to any of the operations R1 to R11

R13:Storage of wastes until they are subjected to any of the procedures listed under R1 to R12 (temporary storage within the area where the waste is produced, excluding collection)

D9: Physical-chemical processes (e.g., evaporation, drying, calcination, and the like) which cause the formation of final compounds or mixtures eluted via any of the processes D1 to D8 and D10 to D12. 


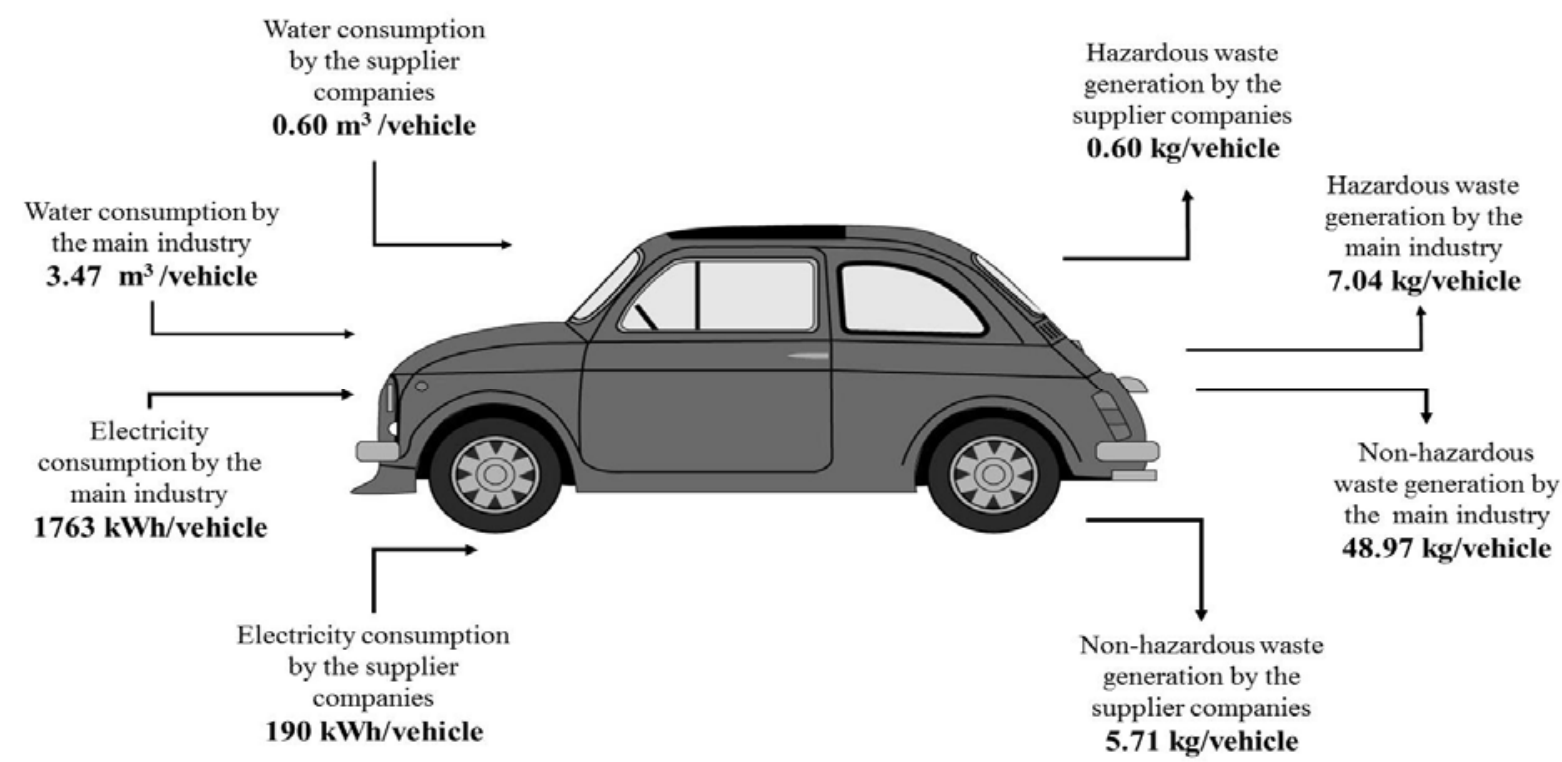

Fig. 9. Levels for resource usage and waste generation during the production of a vehicle by the supplier companies and the OEMs

\subsection{Waste Generated during After Sale Maintenance}

Although each brand and model of all of the vehicles are manufactured by using a different strand of technology, different raw materials etc., the waste generated in after-sale maintenance stage is generally common, and mostly consists of waste oils. Table 3 gives the names and percentages of the wastes generated during the after sales maintenance.

Table 3. Waste Generated During After Sale Maintenance

\begin{tabular}{|c|c|c|}
\hline Name of the waste & $\begin{array}{l}\text { Code of the } \\
\text { Waste }\end{array}$ & Percentage(\%) \\
\hline Containers containing hazardous substances or contaminated with dangerous substances & 150110 & 0 \\
\hline $\begin{array}{l}\text { Dangerous materials contaminated absorbents, filter materials (oil filters if not } \\
\text { otherwise specified), cleaning cloths, protective clothing }\end{array}$ & 150202 & 1 \\
\hline Oil Filters & 160107 & 14 \\
\hline Brake Liquid & 160113 & 1 \\
\hline Leaded Battery & 160601 & 2 \\
\hline End of life tire & 160103 & 2 \\
\hline Other engine, gearbox and lubrication oils & 130208 & 80 \\
\hline
\end{tabular}

\section{Conclusions}

The results of the study implied that despite the large variety of the supplier companies and their sectors, OEMs are the predominant source of waste. Since the supplier companies adapt themselves to the needs of the OEMs, the OEMs have the role to define the environmental standards for the supplier companies. The detailed analysis of the raw material usage and waste generation by the supplier companies showed that these two parameters are not proportional. Waste generation not only depends on the amount of the raw material usage, but also on the efficiency of the process and the characteristics of the item as well. More than 100 different parts are produced by the supplier companies. It was seen that $47 \%$ of the items constituting an automobile is made of plastics, $31 \%$ is made of textile, and $21 \%$ is made of metals. Although a high variety of raw materials and chemicals are being used by the supplier companies, the number and amount of the chemicals used by
OEMs are excessive. It was found that more than 800 tons/year chemicals were consumed by an OEM that produced 400,000 vehicles/year.

The amounts of water and electricity used for all the items by the suppliers were found as $0.60 \mathrm{~m}^{3} /$ vehicle and 190 $\mathrm{kWh} /$ vehicle, respectively. Water and electricity usage by OEMs were $3.47 \mathrm{~m}^{3} /$ vehicle and $1763 \mathrm{kWh} /$ vehicle, respectively. Solid and hazardous waste generated by OEMs were found as $48.97 \mathrm{~kg} /$ vehicle and $7.04 \mathrm{~kg} / \mathrm{vehicle}$, respectively, and by suppliers were $5.71 \mathrm{~kg} /$ vehicle and 0.6 $\mathrm{kg} / \mathrm{vehicle}$, respectively. The sample population in this study is limited to the manufacturing stage of the suppliers in Turkey. Other suppliers worldwide who wish to apply the findings of this study should be conscious of the fact that the resource and waste management practices of the supplier companies may vary between the countries. The maturity of the process technologies used by the suppliers may also vary. 


\section{References}

[1] Liu, Y. J.; Liu, Y.; Chen, J. N., The impact of the Chinese automotive industry: scenarios based on the national environmental goals. Journal of Cleaner Production 2015, 96, 102-109.

[2] Orsato, R. J.; Wells, P., The automobile Industry \& Sustainability. Journal of Cleaner Production 2007, 15, (11-12), 989-993.

[3] Mildenberger, U.; Khare, A., Planning for an environment-friendly car. Technovation 2000, 20, (4), 205-214.

[4] Mayyas, A.; Qattawi, A.; Omar, M.; Shan, D. R., Design for sustainability in automotive industry: A comprehensive review. Renew Sust Energ Rev 2012, 16, (4), 1845-1862.

[5] Vinodh, S.; Jayakrishna, K., Environmental impact minimisation in an automotive component using alternative materials and manufacturing processes. Mater Design 2011, 32, (10), 5082-5090.

[6] Jabbour, C. J. C.; Jabbour, A. B. L. D.; Govindan, K.; Teixeira, A. A.; Freitas, W. R. D., Environmental management and operational performance in automotive companies in Brazil: the role of human resource management and lean manufacturing. Journal of Cleaner Production 2013, 47, 129-140.

[7] Dehning, P.; Thiede, S.; Mennenga, M.; Herrmann, C., Factors influencing the energy intensity of automotive manufacturing plants. Journal of Cleaner Production 2017, 142, 2305-2314.

[8] Sullivan, J. L.; Burnham, A.; Wang, M. Q., Model for the Part Manufacturing and Vehicle Assembly Component of the Vehicle Life Cycle Inventory. J Ind Ecol 2013, 17, (1), 143-153.

[9] Hakamada, M.; Furuta, T.; Chino, Y.; Chen, Y.; Kusuda, H.; Mabuchi, M., Life cycle inventory study on magnesiurn alloy substitution in vehicles. Energy 2007, 32, (8), 1352-1360.

[10] Geyer, R., Parametric assessment of climate change impacts of automotive material substitution. Environ Sci Technol 2008, 42, (18), 6973-6979.

[11] Sim, J.; Sim, J., Air emission and environmental impact assessment of Korean automotive logistics. Journal of Cleaner Production 2017, 159, 130-140.

[12] Vanalle, R. M.; Ganga, G. M. D.; Godinho, M.; Lucato, W. C., Green supply chain management: An investigation of pressures, practices, and performance within the Brazilian automotive supply chain. Journal of Cleaner Production 2017, 151, 250-259.

[13] Mathivathanan, D.; Kannan, D.; Hag, A. N., Sustainable supply chain management practices in Indian automotive industry: A multi-stakeholder view. Resour Conserv Recy 2018, 128, 284-305.

[14] Gunther, H. O.; Kannegiesser, M.; Autenrieb, N., The role of electric vehicles for supply chain sustainability in the automotive industry. Journal of Cleaner Production 2015, 90, 220-233.
[15] Zailani, S.; Govindan, K.; Iranmanesh, M.; Shaharudin, M. R.; Chong, Y. S., Green innovation adoption in automotive supply chain: the Malaysian case. Journal of Cleaner Production 2015, 108, 1115-1122.

[16] Puri, P.; Compston, P.; Pantano, V., Life cycle assessment of Australian automotive door skins. Int J Life Cycle Ass 2009, 14, (5), 420-428.

[17] Ribeiro, I.; Pecas, P.; Silva, A.; Henriques, E., Life cycle engineering methodology applied to material selection, a fender case study. Journal of Cleaner Production 2008, 16, (17), 1887-1899.

[18] Delogu, M.; Zanchi, L.; Maltese, S.; Bonoli, A.; Pierini, M., Environmental and economic life cycle. assessment of a lightweight solution for an automotive component: A comparison between talc-filled and hollow glass microspheres-reinforced polymer composites. Journal of Cleaner Production 2016, 139, 548-560.

[19] Tian, G. D.; Zhang, H. H.; Feng, Y. X.; Jia, H. F.; Zhang, C. Y.; Jiang, Z. G.; Li, Z. W.; Li, P. G., Operation patterns analysis of automotive components remanufacturing industry development in China. Journal of Cleaner Production 2017, 164, 1363-1375.

[20] Handoko, W.; Pahlevani, F.; Emmanuelawati, I.; Sahajwalla, V., Transforming automotive waste into TiN and TiC ceramics. Mater Lett 2016, 176, 17-20.

[21] Liu, P. Y.; Farzana, R.; Rajarao, R.; Sahajwalla, V., Lightweight expanded aggregates from the mixture of waste automotive if plastics and clay. Constr Build Mater 2017, 145, 283-291.

[22] Salihoglu, G.; Salihoglu, N. K., A review on paint sludge from automotive industries: Generation, characteristics and management. Journal of Environmental Management 2016, 169, 223-235.

[23] Tata, Corporate Sustainability Report. Tata Motors Limited 2013, 72 Pages.

[24] Nissan, Sustainability Report. Nissan Motor Company 2014, 143 Pages.

[25] Volkswagen, Sustainability Report. Volkswagen Company 2013, 160 pages.

[26] Toyota, Sustainability Report. Toyota Company, p. 154. 2014.

[27] Volkswagen, Sustainability Report. Volkswagen Company, p. 160. 2013.

[28] Fiat, Sustainability Report: Economic, Environmental and Social Responsiblity. Fiat Comapny 2013, 197 Pages.

[29] ISPAT, T., Turkey's Automotive Industry Report. 2014, Republic of Turkey Prime Ministry Investment Support and Promotion Agency, www.invest.gov.tr.

[30] Salihoglu, G.; Salihoglu, N. K., A review on pant sludge from automotive industries: Generation,characteristics and management. J Environ Manage 2016, 169, 223-235.

[31] USEPA, Introduction to United States Environmental Protection Agency Land Disposal Restrictions (40 CFR Part 268). Solid Waste and Emergency Response (5305W), EPA530-K-05-013 2005, 26 p.

[32] MoEU, Compost Notification. Republic of Turkey, Ministry of Environment and Urbanization, Official Gazette, No:29286, Date: 5 March 20152015. 
[33] Karak, T.; Sonar, I.; Paul, R. K.; Das, S.; Boruah, R. K.; Dutta, A. K.; Das, D. K., Composting of cow dung and crop residues using termite mounds as bulking agent. Bioresource Technology 2014, 169, 731-741.
[34] Gomez-Brandon, M.; Lazcano, C.; Dominguez, J., The evaluation of stability and maturity during the composting of cattle manure. Chemosphere 2008, 70, (3), 436-444. 